\title{
ANALISIS PRODUK KRIMER KENTAL MANIS DALAM RANGKA PENGEMBANGAN STANDAR NASIONAL INDONESIA BARU
}

\section{Analysis of Sweetened Condensed Creamer Products for Development of New Indonesian National Standards}

\author{
Reno Fitri Hasrini dan Ainun Khoiriyah \\ Balai Besar Industri Agro (BBIA), Kementerian Perindustrian \\ JI. Ir. H. Juanda No. 11, Bogor 16122 \\ e-mail: rheefit@yahoo.com
}

Diterima: 18 Oktober 2018, Direvisi: 4 Januari 2018, Disetujui: 5 Januari 2018

\begin{abstract}
Abstrak
Saat ini banyak produk turunan susu yang sulit dibedakan, yaitu susu kental manis (SKM), susu kental manis nabati (SKMN) dan krimer kental manis (KKM). Oleh karena itu perlu dibuat pemetaan konsep syarat mutu untuk ketiga produk tersebut. Belum ada standar nasional dan internasional yang mengatur dan membedakan karakteristik ketiga produk tersebut. Untuk mengetahui karakteristik KKM lokal di Indonesia serta membandingkannya dengan KKM impor, perlu menganalisis berbagai produk KKM lokal dan impor yang beredar di pasar. Bahan yang digunakan adalah KKM lokal 10 merk dan impor 5 merk. Analisis yang dilakukan adalah kadar air, protein ( $\mathrm{Nx} 6,38 \%$ ), lemak total dan kadar gula sebagai sakarosa. Hasil analisis menunjukkan bahwa KKM lokal mempunyai rerata kadar air, protein ( $\mathrm{N} 66,38 \%)$, lemak total dan kadar gula sebagai sakarosa adalah $22,68 \pm 2,51,2,27 \pm 0,14,10,74 \pm 0,89$, dan $47,05 \pm 1,25 \%$ berturut-turut. Sedangkan KKM impor mempunyai rerata

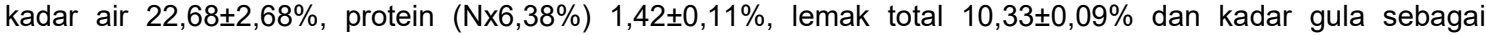
sakarosa $50,5 \pm 2,77 \%$. Kadar air, protein (Nx6,38\%), lemak total dan kadar gula sebagai sakarosa KKM lokal dan impor memenuhi konsep RSNI Krimer Kental Manis dan tidak masuk ke dalam kriteria konsep susu kental manis nabati.
\end{abstract}

Kata kunci: krimer kental manis lokal, krimer kental manis impor, konsep RSNI Krimer Kental Manis, syarat mutu

\begin{abstract}
Currently many milk derivative products are difficult to differentiated, namely sweetened condensed milk (SCM), non dairy sweetened condensed milk (NDSC) and sweetened condensed creamer (SCC). Therefore, it is necessary to mapping the concept of quality requirements for the three products. There are no national and international standards that govern and distinguish the characteristics of the products. To find out the characteristics of local SCC in Indonesia and compare them with imported SCC, it is necessary to analyze various local and imported SCC where circulating in the market. The materials used are local SCC 10 brands and 5 brand imports. The analysis carried out was water content, protein ( $N x 6.38 \%)$, total fat and sugar content as saccharose. The results of the analysis showed that the local SCC had average of water content, protein (Nx6.38\%), total fat and sugar content as saccharose were 22.68 $\pm 2.51,2.27 \pm 0.14,10.74 \pm 0,89$, and $47.05 \pm$ $1.25 \%$, respectively. Whereas imported SCC had average of water content was $22.68 \pm 2.68 \%$, protein (Nx6.38\%) was $1.42 \pm 0.11 \%$, total fat was $10.33 \pm 0.09 \%$ and sugar content as saccharose was $50.5 \pm 2.77 \%$. Quality requirements for local and imported SCC suitable for the Indonesian National Standard Concept of sweetened condensed creamer and were not suitable with quality requirements of non dairy sweetened condensed milk concept.
\end{abstract}

Keyword: local sweetened condensed creamer, imported sweetened condensed creamer, Indonesian National Standard Concept of sweetened condensed creamer, quality requirements

\section{PENDAHULUAN}

Saat ini banyak beredar berbagai jenis produk susu dan turunannya. Mulai dari susu segar, susu pasteurisasi, susu UHT, susu bubuk, hingga susu kental manis yang memiliki masa kadaluarsa yang panjang (Tantya et al. 2013). Selain produk susu yang kandungan susunya tinggi, beredar pula produk turunan susu yang sedikit mengandung susu dan dilakukan penambahan minyak nabati. Salah satu produk turunan susu yang banyak dikonsumsi oleh masyarakat adalah krimer kental manis (Rosida et al., 2016).

Krimer kental manis (KKM) adalah produk pengganti susu atau krim yang merupakan produk emulsi lemak dalam air, dibuat dari 
minyak nabati yang dihidrogenasi dengan penambahan bahan tambahan pangan yang diizinkan (Putri et al., 2016). Krimer kental manis umumnya digunakan untuk menambah cita rasa pada makanan dan minuman (Noor, 2011).

Belakangan ini, banyak produk yang sulit dibedakan antara susu kental manis (SKM), susu kental manis nabati (SKMN) dan krimer kental manis (KKM). Oleh karena itu dibuat pemetaan konsep syarat mutu untuk ketiga produk tersebut. Parameter yang dijadikan syarat mutu adalah kadar air, protein $(\mathrm{Nx} 6,38)$, lemak total dan gula (sakarosa). Belum ada standar nasional dan internasional yang mengatur dan membedakan karakteristik produk krimer kental manis dengan produk susu kental manis dan susu kental manis nabati. Tujuan dari penelitian ini adalah untuk mengetahui karakteristik krimer kental manis di Indonesia dan menetapkan konsep SNI KKM.

\section{TINJAUAN PUSTAKA}

\subsection{Definisi dan Kegunaan Krimer Kental Manis}

Krimer kental manis (KKM) adalah produk susu yang berbentuk cairan kental, yang diperoleh dari susu yang telah ditambahkan gula dan lemak nabati yang kemudian sebagian air dihilangkan hingga mencapai kepekatan tertentu, atau merupakan hasil rekonstitusi susu bubuk dengan penambahan gula dan lemak nabati/minyak nabati dan bahan lain (BPOM, 2016).

Gula yang ditambahkan harus dapat mencegah kerusakan produk. Produk dipasteurisasi dan dikemas secara kedap (hermetis). Produk ini disebut krimer nabati karena memanfaatkan minyak nabati sebagai bahan baku seperti halnya pemanfaatan lemak susu dalam produk krimer (Dian dan Sahri, 2017). Kelebihan lain yang dimiliki oleh krimer nabati antara lain umur simpan produk yang lebih panjang, kemudahan dalam penyimpanan, distribusi dan penanganan, selain itu non dairy creamer aman bagi penderita lactose intolerance karena terbuat dari lemak nabati yang tidak mengandung laktosa (Nguyen et al., 2016). Formulasi yang tepat akan menghasilkan creamlike flavour dan tekstur yang diharapkan sangat mirip dengan krim susu (Chawla et al., 2011).

Krimer kental manis mengandung protein yang lebih rendah dari susu kental manis, biasanya digunakan terutama sebagai topping olesan roti, pelengkap atau campuran kopi, bahan baku kue/bolu, bahan baku ice cream, martabak, es campur, puding, dan es soda. Krimer kental manis termasuk produk non dairy creamer (krimer non susu) yang digunakan sebagai pengganti krimer berbahan baku susu, susu evaporasi atau susu segar (Nguyen et al., 2016).

\subsection{Kriteria Mutu KKM}

Krimer kental manis belum mempunyai standar nasional. Standar internasional yang mengatur standar KKM juga masih sangat terbatas yaitu Codex (2006) yang mengatur kadar lemak minimal $8 \%$. Jenis krimer yang umum dikenal adalah krimer nabati bubuk sehingga krimer kental manis masih belum ada standar internasionalnya. Rapat teknis, prakonsensus dan konsensus KKM telah dilakukan dan berdasarkan kesepakatan Sub Komite Teknis 67-04-S1 Minuman, industri, tenaga ahli dan konseptor, kriteria konsep KKM dan SKMN adalah kadar air, kadar protein, kadar lemak dan kadar gula dihitung sebagai sakarosa. Cemaran mikroba mengikuti Perka BPOM No. 16 tentang Kriteria Mikrobiologi dalam Pangan Olahan (BPOM, 2016) sehingga tidak dilakukan pengujian cemaran mikroba pada produk KKM.

Kadar air menentukan keawetan produk karena kadar air yang tinggi akan membuat bakteri, kapang, dan khamir mudah tumbuh (Winarno, 1997). Kadar protein menggambarkan kandungan susu dalam produk sehingga perlu diuji. Lemak total menunjukkan kadar lemak dari berbagai komponen di dalam KKM, serta kadar gula (dihitung sebagai sakarosa) menjadi indikasi viskositas dan sebagai pengawet alami pada KKM.

\section{METODE PENELITIAN}

\subsection{Bahan}

Bahan yang digunakan adalah krimer kental manis (KKM) lokal dan impor masing-masing berjumlah 10 dan 5 sampel. Bahan-bahan analisis seperti $\mathrm{H}_{2} \mathrm{SO}_{4}$ pekat, $\mathrm{NaOH}$, asam borat, heksana, larutan asam klorida, $\mathrm{HCL}$, kertas lakmus, $\mathrm{HCL}$, petroleum eter, $\mathrm{H}_{2} \mathrm{SO}_{4}$, amil alkohol, $\mathrm{NH}_{4} \mathrm{OH}$, etanol, dietil eter, $\mathrm{Na}_{2} \mathrm{CO}_{3}$ anhidrat, asam sitrat, $\mathrm{CuSO}_{4} \cdot 5 \mathrm{H}_{2} \mathrm{O}, \mathrm{KI}$, amilum, $\mathrm{NaOH}$, indikator fenolftalen, $\mathrm{Zn}$ asetat $2 \mathrm{H}_{2} \mathrm{O}$, dan $\mathrm{K}_{4} \mathrm{Fe}(\mathrm{CN})_{6}$ diperoleh dari E. Merck.

\subsection{Metode Analisis}

Penelitian ini dilakukan pada bulan Juli-Desember 2018. Pengujian mutu dilakukan di Laboratorium Pengujian Balai Besar Industri Agro. Parameter mutu yang dianalisis adalah kadar air, kadar protein, kadar lemak dan jumlah gula (dihitung sebagai sakarosa). Metode analisis kadar air dan protein mengacu kepada SNI 01-2891-1992 Cara uji makanan dan minuman (BSN, 1992). Metode analisis kadar lemak mengacu SNI 2971:2011 Susu kental manis (BSN, 2011) dan metode analisis jumlah gula (dihitung sebagai sakarosa) mengacu SNI 01-2892-1992 Cara uji gula madu (BSN, 1992). 
Tabel 1 Syarat mutu krimer kental manis lokal, impor, konsep KKM dan SKMN.

\begin{tabular}{|c|c|c|c|c|c|c|c|c|}
\hline \multirow{2}{*}{ No. } & \multirow[t]{2}{*}{ Parameter } & \multicolumn{2}{|c|}{ KKM Lokal } & \multicolumn{2}{|c|}{ KKM Impor } & \multirow[b]{2}{*}{$\begin{array}{l}\text { Konsep } \\
\text { Krimer } \\
\text { Kental } \\
\text { Manis } \\
\text { (KKM) }\end{array}$} & \multirow[b]{2}{*}{$\begin{array}{l}\text { Konsep } \\
\text { Susu } \\
\text { Kental } \\
\text { Manis } \\
\text { Nabati } \\
\text { (SKMN) }\end{array}$} & \multirow{2}{*}{$\begin{array}{l}\text { Codex } \\
\text { Stan } \\
(2016)\end{array}$} \\
\hline & & Rerata & Kisaran & Rerata & Kisaran & & & \\
\hline 1. & Air (\%) & $\begin{array}{l}22,68 \pm 2 \\
51\end{array}$ & $\begin{array}{l}19,5- \\
25,8\end{array}$ & $\begin{array}{l}22,68 \pm 2,6 \\
8\end{array}$ & $19,9-25,6$ & $20-30$ & $20-30$ & - \\
\hline 2. & $\begin{array}{l}\text { Protein } \\
(\mathrm{Nx6}, 38) \\
(\%)\end{array}$ & $\begin{array}{l}2,27 \pm 0,1 \\
4\end{array}$ & $\begin{array}{l}2,13- \\
2,63\end{array}$ & $1,42 \pm 0,11$ & $1,32-1,42$ & $\begin{array}{l}\text { Tidak kurang } \\
\text { dari } 1 \%\end{array}$ & $2-<6,5$ & - \\
\hline 3. & $\begin{array}{l}\text { Lemak total } \\
(\%)\end{array}$ & $\begin{array}{l}10,74 \pm 0 \\
89\end{array}$ & $\begin{array}{l}9,75- \\
12,7\end{array}$ & $\begin{array}{l}10,33 \pm 0,0 \\
9\end{array}$ & $\begin{array}{l}10,32- \\
10,40\end{array}$ & $\begin{array}{l}\text { Tidak kurang } \\
8 \%\end{array}$ & $\begin{array}{l}\text { Tidak } \\
\text { kurang } 8 \%\end{array}$ & $\min .8$ \\
\hline 4. & $\begin{array}{l}\text { Kadar gula } \\
\text { (sakarosa) } \\
(\%)\end{array}$ & $\begin{array}{l}47,05 \pm 1 \\
25\end{array}$ & $\begin{array}{l}44,0- \\
48,1\end{array}$ & $50,5 \pm 2,77$ & $47,7-50,6$ & $\geq 42 \%$ & $\geq 42 \%$ & - \\
\hline
\end{tabular}
(\%)

Keterangan: Rerata \pm standar deviasi

\section{HASIL DAN PEMBAHASAN}

Parameter yang dianalisis untuk sampel krimer kental manis lokal dan impor adalah kadar air, kadar protein, kadar lemak dan kadar gula dihitung sebagai sakarosa. Kadar air merupakan parameter utama dalam syarat mutu RSNI KKM. Kadar air sangat penting, karena dapat memengaruhi penampakan, tekstur, dan cita rasa pada KKM. Kadar air dalam bahan pangan ikut menentukan kesegaran dan daya awet bahan pangan tersebut, kadar air yang tinggi mengakibatkan mudahnya bakteri, kapang, dan khamir untuk berkembang biak, sehingga akan terjadi perubahan pada bahan pangan (Winarno, 1997). Hasil analisis akan dibandingkan dengan kriteria konsep KKM, SKMN dan Codex Stan (2016).

\subsection{Kadar Air}

Hasil analisis kadar air (KA) menunjukkan bahwa KA KKM lokal $22,68 \pm 2,51 \%$ dan KKM impor sebesar 22,68 $\pm 2,68 \%$, sedangkan pada Codex tidak ditentukan. Nilai ini memenuhi kriteria KA konsep KKM yaitu 20-30\%. Pada umumnya kadar air cenderung menurun pada kurun waktu tertentu seiring bertambahnya suhu perlakuan, karena selama proses penguapan suhu yang lebih tinggi akan memengaruhi kecepatan evaporasi sehingga kandungan air bahan teruapkan lebih banyak. Pengolahan KKM di Indonesia dapat dilakukan dengan dua cara, yaitu menguapkan susu dari evaporator vakum pada tekanan dan suhu tertentu, sampai diperoleh kekentalan yang dikehendaki atau total padatan telah mencapai $70-80 \%$ dan kadar air $20-30 \%$, atau melakukan rekonstitusi kembali bahan-bahan baku KKM hingga membentuk emulsi yang cukup kental. Untuk memperoleh KKM yang lebih kental, dilakukan penguapan sebagian air dari campuran tersebut. Dengan cara rekonstitusi, jumlah air yang harus diuapkan pada pembuatan SKM jauh lebih sedikit, karena total padatan yang diperoleh dari hasil rekonstitusi telah mencapai 70,7-70,9\% (Maharani, 2017).

\subsection{Kadar Protein}

Parameter utama yang membedakan SKM, SKMN dan KKM adalah kadar proteinnya. Kadar protein menggambarkan kandungan susu dalam produk-produk tersebut. Pengujian kadar protein KKM lokal dan impor pada Tabel 1 menunjukkan bahwa rerata kadar protein KKM lokal lebih tinggi daripada KKM impor yaitu $2,27 \pm 0,14 \%$ dan $1,42 \pm 0,11 \%$ berturut-turut. Skim milk powder digunakan sebagai sumber protein susu dengan kadar air maksimal 1\% dan kadar lemak kurang dari 15\% (Hidayah, 2010). Susu skim adalah bagian susu yang tertinggal sesudah krim diambil sebagian atau seluruhnya. Susu skim mengandung semua zat makanan dari susu kecuali lemak dan vitamin-vitamin yang larut dalam lemak (Buckle et al., 1987).

Peningkatan kadar protein berbanding terbalik dengan penambahan minyak nabati pada KKM tersebut. Semakin besar penambahan minyak nabati maka semakin rendah kadar proteinnya. Nilai kadar protein KKM lokal ternyata lebih besar daripada KKM impor, nilai tersebut juga lebih masuk ke syarat mutu konsep susu kental manis nabati daripada krimer kental manis, sedangkan KKM impor lebih masuk ke konsep KKM. Syarat kadar protein pada konsep susu kental manis yang penambahan minyak nabatinya tidak sebanyak KKM adalah diatas $2 \%$ dan dibawah $6,5 \%$, sedangkan kadar protein pada syarat mutu KKM.

\subsection{Lemak Total}

Kadar lemak total menggambarkan konsentrasi lemak yang terkandung di dalam KKM. Tabel 1 menunjukkan bahwa rerata kadar lemak total dari KKM lokal dan impor adalah $10,74 \pm 0,89 \%$ dan $10,32-10,40 \%$. Nilai ini memenuhi konsep syarat mutu SKMN dan KKM yaitu tidak kurang dari $8 \%$, tapi tidak memenuhi syarat mutu Codex minimal 
8\%. Lemak total pada KKM dikontribusi oleh minyak nabati umumnya adalah RBDPO (Refined Bleached Deodorized Palm Oil) yang merupakan minyak sawit yang telah dihilangkan warna dan baunya. Tujuan penambahan RBDPO untuk meningkatkan kandungan lemak dan memperbaiki tekstur pada KKM (Deviyanti, 2008).

\subsection{Kadar Gula sebagai Sukrosa}

Kadar gula sebagai sukrosa pada KKM lokal dan impor sebesar 47,05 $\pm 1,25$ dan 47,7-50,6\%. Gula yang digunakan dalam pembuatan SKM adalah gula pasir atau sukrosa. Nilai ini memenuhi kriteria KKM dan SKMN yaitu minimal atau sama dengan $42 \%$. Konsentrasi gula di dalam fase air harus tidak kurang dari $62.5 \%$ dan tidak lebih dari $64.5 \%$. Konsentrasi larutan diatas $64.5 \%$, gula akan mengalami titik jenuhnya dan beberapa akan mengalami kristalisasi, dan membentuk sedimen (Spreer, 2017).

Gula pada KKM adalah mempunyai fungsi memberikan rasa manis, meningkatkan viskositas, dan meningkatkan umur simpan dalam pembuatan KKM. Gula mempunyai sifat higroskopis, sehingga mampu menyerap kandungan air pada produk susu kental manis serta meningkatkan tekanan osmotik pada suatu tingkat tertentu dimana kebanyakan mikroorganisme dihancurkan. Sifat higroskopis yang dimiliki oleh gula dapat menurunkan Aw dan dapat menghambat tumbuhnya bakteri dan fermentasi pada produk KKM (Sitaresmi, 2006).

\section{KESIMPULAN}

Krimer kental manis lokal mempunyai rerata kadar air, protein $(\mathrm{N} \times 6,38 \%)$, lemak total dan kadar gula sebagai sakarosa adalah $22,68 \pm 2,51$, $2,27 \pm 0,14$, 10,74 $\pm 0,89$, dan $47,05 \pm 1,25 \%$ berturut-turut. Sedangkan krimer kental manis impor mempunyai rerata kadar air 22,68 $22,68 \%$, protein $(\mathrm{Nx} 6,38 \%) \quad 1,42 \pm 0,11 \%$, lemak total $10,33 \pm 0,09 \%$ dan kadar gula sebagai sakarosa $50,5 \pm 2,77 \%$. Syarat mutu krimer kental manis lokal dan impor memenuhi konsep RSNI Krimer Kental Manis dengan syarat mutu kadar air 20$30 \%$, kadar protein tidak kurang dari $1 \%$, kadar lemak total tidak kurang dari $8 \%$ dan kadar gula sebagai sakarosa minimal sama atau lebih $42 \%$.

\section{UCAPAN TERIMAKASIH}

Penulis mengucapkan terimakasih kepada Subdirektorat Industri Pengolahan Susu dan Minuman Lainnya, Direktorat Industri Minuman, Hasil Tembakau, dan Bahan Penyegar, Direktorat Jenderal Industri Agro, Kementerian Perindustrian yang telah mendanai analisis produk Krimer Kental Manis ini. Ucapan terimakasih juga kami sampaikan kepada pihakpihak yang mendukung penelitian ini.

\section{DAFTAR PUSTAKA}

Badan Standardisasi Nasional. (1992). SNI 012891-1992. Cara Uji Makanan dan Minuman, Jakarta.

Badan Standardisasi Nasional. (1992). SNI 012892-1992 Cara Uji Gula Madu. Jakarta.

Badan Standardisasi Nasional. (2011). SNI 2971:2011-Susu Kental Manis, Jakarta.

BPOM. 2016. Keputusan Kepala Badan Pengawas Obat dan Makanan Republik Indonesia No. HK.00.05.52.4040 Tentang Kategori Pangan. Badan Pengawas Obat dan Makanan Republik Indonesia. Jakarta.

Buckle, K.A., R.A, Edwards, G.H. Fleet \& M. Wooton. (1985). Ilmu Pangan. Terjemahan Purnomo dan Adiono. Jakarta: UI Press

Bylund G. (1995). Dairy Processing Handbook. Lund: Tetra Pak Processing Systems AB. hlm $353-359$.

Chawla, R., Patil, G.R. \& Singh, A.K. (2011). High hydrostatic pressure technology in dairy processing: a review. J Food Sci Technol. $48: 260$ https://doi.org/10.1007/s13197-010-01804

Codex Stan 250-2006. (2006). Codex Standard for A Blend Of Sweetened Condensed Skimmed Milk and Vegetable Fat (Amendment 2010).

Deviyanti C. 2008. Penerapan teknik perbaikan mutu dalam mengatasi defect pada pengemasan susu kental manis dan kremer kental manis kaleng di PT. Indolakto, Jakarta. Skripsi. Departemen IImu Dan Teknologi Pangan Fakultas Teknologi Pertanian. Institut Pertanian Bogor. Bogor.

Dian N.L.H.M. \& M.M. Sahri. (2017). Palm-Based Multipurpose Liquid Creamer. MPOB Information Series. ISSN 1511-7871.

Hidayah, N. (2010). Teknik perbaikan mutu dalam mengatasi defect pada pengemasan susu kental manis sachet di PT Frisian Flag Indonesia, Jakarta. Skripsi. Fakultas Peternakan. Institut Pertanian Bogor, Bogor.

Maharani, P.M. (2017). Laporan kerja praktek di PT Frisian Flag Indonesia Plant Ciracas. Program Studi Teknik Industri Fakultas Teknologi Industri Universitas Atma Jaya Yogyakarta. 
Nguyen, T T, H.M. Nguyen, A. Jarunrattanasri \& Singanusong, R. (2016). Production and quality of sterilized liquid non-dairy creamer from refined rice bran oil. Proceeding of The 18th Food Innovation Asia Conference 2016 (Fiac 2016). 16-18 June 2016, Bangkok, Thailand.

Noor A.S.R. (2011). Optimasi pencampuran pada proses produksi susu kental manis lemak nabati rekombinasi (studi kasus PT. XYZ). Tesis. Sekolah Pasca Sarjana Institut Pertanian Bogor. Bogor.

Peraturan Kepala Badan Pengawas Obat dan Makanan Nomor 16 Tahun 2016 tentang Kriteria Mikrobiologi dalam Pangan Olahan.

Putri, H.L.R., Hidayati A, Widyaningsih T.D., Wijayanti N. \& J.M. Maligan. (2014). Pengendalian kualitas non dairy creamer pada kondisi proses pengeringan semprot di PT. Kievit Indonesia, Salatiga: Kajian Pustaka. J Pangan dan Agroindustri 4(1):443-448.
Rosida D.F., Mulyani T., \& Reshita S.L. (2016). A Comparative study of non-dairy cream based on the type of leguminosae protein source in terms of physico chemical properties and organoleptic. Agriculture and Agricultural Science Procedia. 9: 431 -439 .

Sitaresmi, F. (2006). Penerapan statistical process control (SPC) dalam mengendalikan kebocoran kemasan susu kental manis sachet di PT Frisian Flag Indonesia Plant Pasar Rebo, Jakarta Timur. Skripsi. Fakultas Teknologi Pertanian. Institut Pertanian Bogor, Bogor.

Tantya, A.T. (2013). Evaluasi proses pengemasan untuk mengurangi persentase kerusakan kemasan dari susu kental manis sachet di PT Frisian Flag Indonesia Jakarta. Skripsi. Departemen Ilmu Produksi dan Teknologi Peternakan Fakultas Peternakan Institut Pertanian Bogor. Bogor.

Winarno, F.G. (1997). Kimia pangan dan gizi. Gramedia Pustaka Utama. 253 hal. 